Published in final edited form as:

J Am Chem Soc. 2019 January 09; 141(1): 80-83. doi:10.1021/jacs.8b11045.

\title{
A Mononuclear Nonheme Iron(IV)-Amido Complex Relevant for the Compound II Chemistry of Cytochrome P450
}

\author{
Xiaoyan Lu ${ }^{\dagger}$, Xiao-Xi $\mathrm{Li}^{\dagger}$, Mi Sook Seo ${ }^{\dagger}$, Yong-Min Lee ${ }^{\dagger}$, Martin Clémancey ${ }^{\ddagger}$, Pascale

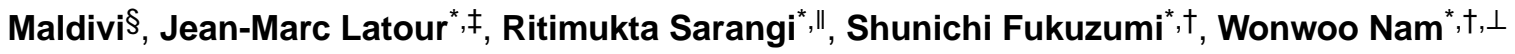 \\ tDepartment of Chemistry and Nano Science, Ewha Womans University, Seoul 03760, Korea \\ ‡Université Grenoble Alpes, CEA, CNRS, BIG, LCBM, Grenoble F-38000, France \\ §Université Grenoble Alpes, CEA, CNRS, INAC, SYMMES, Grenoble F-38000, France \\ "Stanford Synchrotron Radiation Lightsource, SLAC National Accelerator Laboratory, Stanford, \\ California 94025, United States \\ ${ }^{\perp}$ State Key Laboratory for Oxo Synthesis and Selective Oxidation, Suzhou Research Institute of \\ LICP, Lanzhou Institute of Chemical Physics (LICP), Chinese Academy of Sciences, Lanzhou \\ 730000, China
}

\section{Abstract}

\begin{abstract}
A mononuclear nonheme iron(IV)-amido complex bearing a tetraamido macrocyclic ligand, $\left[(\mathrm{TAML}) \mathrm{Fe}^{\mathrm{IV}}(\mathrm{NHTs})\right]^{-}(\mathbf{1})$, was synthesized via a hydrogen atom (H atom) abstraction reaction of an iron(V)-imido complex, [(TAML) $\left.\mathrm{Fe}^{\mathrm{V}}(\mathrm{NTs})\right]^{-}$(2), and fully characterized using various spectroscopies. We then investigated (1) the $\mathrm{p} K_{\mathrm{a}}$ of $\mathbf{1},(2)$ the reaction of $\mathbf{1}$ with a carbon-centered radical, and (3) the $\mathrm{H}$ atom abstraction reaction of $\mathbf{1}$. To the best of our knowledge, the present study reports for the first time the synthesis and chemical properties/reactions of a high-valent iron(IV)-amido complex.
\end{abstract}

\begin{abstract}
Heme and nonheme iron enzymes as well as their synthetic model compounds catalyze the hydroxylation of alkanes with high efficiency and selectivity. ${ }^{1-3}$ High-valent iron(IV)-oxo porphyrin $\pi$-cation radical species $\left(\right.$ Porp $\left.^{+\bullet}\right)-\mathrm{Fe}^{\mathrm{IV}}(\mathrm{O})$, referred to as compound $\mathrm{I}(\mathrm{Cpd}-\mathrm{I})$, are the key intermediates responsible for the $\mathrm{C}-\mathrm{H}$ hydroxylation of substrates in heme systems; a hydrogen atom is abstracted from substrate $\mathrm{C}-\mathrm{H}$ bonds by $\mathrm{Cpd}-\mathrm{I}$ (Scheme 1A, reaction a), followed by a fast oxygen rebound between the $\mathrm{Fe}(\mathrm{IV})-\mathrm{OH}$ porphyrin species, referred to as compound II (Cpd-II), and the carbon radical (Scheme 1A, reaction $b$ ). ${ }^{1,4}$ Since the $\mathrm{H}$ atom abstraction by Cpd-I is the rate-determining step (rds) (Scheme 1A, reaction a), the Orebound step has never been observed directly (Scheme 1A, reaction $b$ ). However, very recently, Goldberg and co-workers reported the first direct O-rebound process, in which an
\end{abstract}

\footnotetext{
*Corresponding Authors: jean-marc.latour@cea.fr, ritis@slac.stanford.edu, fukuzumi@chem.eng.osaka-u.ac.jp,wwnam@ewha.ac.kr. ASSOCIATED CONTENT

Supporting Information

The Supporting Information is available free of charge on the ACS Publications website at DOI: 10.1021/jacs.8b11045.

Experimental Section, Tables S1-S3, and Figures S1-S35 (PDF)

The authors declare no competing financial interest.
} 
iron(IV)-hydroxide corrole complex, $\left[\mathrm{Fe}^{\mathrm{IV}}(\mathrm{OH})\right],{ }^{5}$ and a nonheme iron(III)-methoxide complex, $\left[\mathrm{Fe}^{\mathrm{III}}\left(\mathrm{OCH}_{3}\right)\right],{ }^{6}$ were utilized in reactions with carbon-centered radicals. In the study, they demonstrated the $\mathrm{C}-\mathrm{O}$ bond formation between $\mathrm{Fe}-\mathrm{OX}\left(\mathrm{X}=\mathrm{H}\right.$ and $\left.\mathrm{CH}_{3}\right)$ and carbon radicals. 5,6

Another interesting subject that has attracted much attention recently is the basicity of the Cpd-II Fe(IV)-OH; ${ }^{1 b, 7,8}$ the basicity of the $\mathrm{Fe}(\mathrm{IV})-\mathrm{OH}$ species is an important factor that determines the reactivity of $\mathrm{Cpd}-\mathrm{I}$ in $\mathrm{C}-\mathrm{H}$ activation reactions and that the strong electrondonating ability of the thiolate axial ligand increases the basicity of the iron-oxo moiety, influencing the reactivity of Cpd-I in $\mathrm{H}$ atom abstraction reactions. Indeed, $\mathrm{p} K_{\mathrm{a}} \mathrm{s}$ of several $\mathrm{Fe}(\mathrm{IV})-\mathrm{OH}$ intermediates were determined in heme enzymes, ${ }^{7,8}$ showing that $\mathrm{Cpd}$-II with a high $\mathrm{p} K_{\mathrm{a}}$ is more reactive in $\mathrm{C}-\mathrm{H}$ bond activation reactions.

High-valent iron-imido $(\mathrm{Fe}=\mathrm{NR})$ and iron-amido $(\mathrm{Fe}-\mathrm{NHR})$ species, which are iron-oxo $(\mathrm{Fe}=\mathrm{O})$ and iron-hydroxo $(\mathrm{Fe}-\mathrm{OH})$ analogs, respectively, have been proposed as reactive intermediates in nitrogen group transfer reactions. ${ }^{9}$ Very recently, we reported that a high-

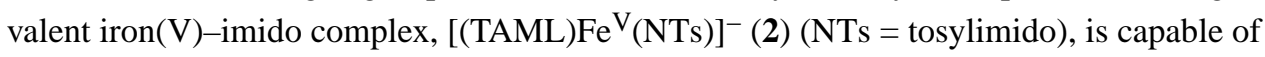
activating $\mathrm{C}-\mathrm{H}$ bonds of substrates (Scheme 1B). ${ }^{10}$ In the amination reactions, an iron(IV)amido intermediate, [(TAML) $\left.\mathrm{Fe}^{\mathrm{IV}}(\mathrm{NHTs})\right]^{-}(\mathbf{1})$, is generated as a transient intermediate (Scheme 1B, reaction a), as Cpd-II is proposed as a transient intermediate in heme systems (compare Scheme 1A and B). Then, the iron(IV)-amido intermediate is recombined with the carbon radical to yield an aminated product and an iron(III) product (Scheme 1B, reaction b). Encouraged by the successful synthesis of the $\mathrm{Fe}(\mathrm{V})-\mathrm{NTs}$ complex and the reaction of the $\mathrm{Fe}(\mathrm{V})-\mathrm{NTs}$ complex with alkane $\mathrm{C}-\mathrm{H}$ bonds, ${ }^{10 \mathrm{a}}$ we attempted to synthesize an $\mathrm{Fe}(\mathrm{IV})-$ NHTs complex as an analog of Cpd-II and investigated the chemical properties/reactions of the Fe(IV)-NHTs complex in various aspects. Herein, we report a novel high-valent iron(IV)-amido complex, [(TAML) $\left.\mathrm{Fe}^{\mathrm{IV}}(\mathrm{NHTs})\right]^{-}$(1), which is synthesized via a $\mathrm{H}$ atom abstraction reaction of $\mathbf{2}$ (Scheme 2, reaction a). We also report the $\mathrm{p} K_{a}$ determination, nitrogen rebound, and $\mathrm{H}$ atom abstraction reactions of the Fe(IV)-NHTs complex (Scheme 2).

The mononuclear iron(V)-imido complex [(TAML)- $\left.\mathrm{Fe}^{\mathrm{V}}(\mathrm{NTs})\right]^{-}$(2) was synthesized according to the literature procedures. ${ }^{10}$ Upon addition of 1 equiv of TEMPOH $(=2,2,6,6$ tetramethylpiperidin-1-ol) or excess amounts of 9,10-dihydroanthracene (DHA) or 1,4cyclohexadiene (CHD) to 2 in $\mathrm{CH}_{3} \mathrm{CN}(\mathrm{MeCN})$ at $-40{ }^{\circ} \mathrm{C}$, the color of the reaction solution changed from dark green to purple (Supporting Information (SI), Experimental Section). The purple intermediate $(\mathbf{1})$ was metastable $\left(t_{1 / 2} \approx 3 \mathrm{~h}\right)$ at $-40{ }^{\circ} \mathrm{C}$, allowing us to characterize it using various spectroscopies, such as UV-vis, cold spray time-of-flight mass spectrometry (CSI-MS), electron paramagnetic resonance (EPR), Mössbauer, and X-ray absorption spectroscopy/extended X-ray absorption fine structure (XAS/EXAFS). The UVvis spectrum of 1 exhibited two distinct absorption bands at $526\left(\varepsilon=6100 \mathrm{M}^{-1} \mathrm{~cm}^{-1}\right)$ and $690 \mathrm{~nm}\left(\varepsilon=3600 \mathrm{M}^{-1} \mathrm{~cm}^{-1}\right)$ (Figure 1a; Figures S1-S3). CSI-MS of 1 in negative mode exhibited a prominent ion peak at $\mathrm{m} / \mathrm{z}$ of 596.1, with mass and isotope distribution patterns corresponding to [(TAML)Fe(NHTs) $]^{-}$(calculated $\mathrm{m} / \mathrm{z}$ of 596.1) (Figure 1a, inset). When 1 was generated using ${ }^{15} \mathrm{~N}$-labeled 2 , [(TAML) $\left.\mathrm{Fe}^{\mathrm{V}}\left({ }^{15} \mathrm{NTs}\right)\right]^{-}$, one-mass-unit shift from 596.1 to 597.1 was observed (Figure 1a, inset; Figures S4 and S5, inset). This result demonstrates 
that $\mathbf{1}$ contains one NHTs group. The X-band EPR spectrum of $\mathbf{1}$ was silent when $\mathbf{1}$ was generated using DHA or CHD (Figure S6). However, when 1 was generated using TEMPOH, the EPR spectrum of the reaction solution showed signals at $g \sim 2.0$ from TEMPO• (Figure S7).

1 was also analyzed with Mössbauer spectroscopy (Figure 1b). The spectrum recorded at 80 $\mathrm{K}$ without applied magnetic field is constituted by a quadrupole doublet accounting for $97 \%$ of the sample iron, with hyperfine parameters consistent with an $S=1 \mathrm{Fe}(\mathrm{IV})$ species. This assignment was confirmed by experiments at $4.5 \mathrm{~K}$ at 0 and $7 \mathrm{~T}$ (Figure S8). A global simulation of all spectra resulted in the following parameters: $\delta=-0.00 \mathrm{~mm} \mathrm{~s}^{-1}, \Delta \mathrm{E}_{\mathrm{Q}}=3.33$ $\mathrm{mm} \mathrm{s}^{-1}$, and $D=15 \mathrm{~cm}^{-1}$ (Table S1), which match with those reported for other Fe(IV) complexes of related ligands. ${ }^{11}$

Fe K-edge XAS was performed on solutions of $\mathbf{1}$ and $\mathbf{2}$, and the data are presented in Figure 2a. The data show that the rising edge of $\mathbf{1}$ is $\sim 1 \mathrm{eV}$ lower in energy relative to $\mathbf{2}$. A comparison of the pre-edge region is present in the inset of Figure 2a, which shows that the pre-edge energy position of $\mathbf{1}$ has shifted to lower energy by $\sim 0.5 \mathrm{eV}(7112.9 \mathrm{eV}$ in $\mathbf{2}$ to $7112.4 \mathrm{eV}$ in $\mathbf{1}$ ), and the intensity has decreased significantly in $\mathbf{1}$ relative to $\mathbf{2}$. This lowering of pre-edge energy position and decrease in intensity suggest a change in the $\mathrm{Fe}-\mathrm{N}$ axial interaction on going from $\mathbf{2}$ to $1{ }^{10 b, 12,13} \mathrm{Fe}$ K-edge EXAFS data for $\mathbf{1}$ and $\mathbf{2}$ were measured and analyzed for local structure determination. A comparison is shown in Figure $2 \mathrm{~b}$, and fits to the data of $\mathbf{1}$ are shown in Figure S9 and Table S2. The best fits to the data for 1 reveal a first shell devoid of a short $\mathrm{Fe}-\mathrm{N}$ interaction and consistent with either four or five $\mathrm{Fe}-\mathrm{N}$ interactions at $1.89 \AA$ (Table S2), suggesting elongation of the $\mathrm{Fe}-\mathrm{N}$ relative to $\mathbf{2}$. These data are supported by TD-DFT simulations of the Fe K-edge pre-edge region on the triplet ground state structure of a five-coordinate $\mathbf{1}$ and comparing that to that of $\mathbf{2}$. The TDDFT calculations (Figure S10) reveal an excellent agreement with the Fe K-pre-edge data, supporting the five-coordinate EXAFS fit. Based on the spectroscopic characterization and the density functional theory (DFT) calculations (see Figure S11 for the DFT-optimized structure; Table S3), 1 can be assigned as an $S=1$ iron(lV)-amido complex with a single Fe$\mathrm{N}$ bond, [(TAML) $\left.\mathrm{Fe}^{\mathrm{IV}}(\mathrm{NHTs})\right]^{-}$.

We then investigated the $\mathrm{p} K_{\mathrm{a}}$ of $\mathrm{Fe}(\mathrm{IV})-\mathrm{N}(\mathrm{H}) \mathrm{Ts}$ by the spectroscopic titration with bases in $\mathrm{MeCN}$ at $-40{ }^{\circ} \mathrm{C}$ (Scheme 2, reaction $\left.b\right)$. When 1 was reacted with pyridine $\left(\mathrm{p} K_{\mathrm{a}}=12.3\right)^{14}$ and 2-aminopyridine $\left(\mathrm{p} K_{\mathrm{a}}=14.3\right),{ }^{14}$ we did not observe any spectral changes in the reactions. However, addition of 1 equiv of 4-dimethylaminopyridine (4-DMAPy, $\mathrm{p} K_{\mathrm{a}}=$ $17.6)^{14}$ or 4-aminopyridine (4-APy, $\left.\mathrm{p} K_{\mathrm{a}}=17.2\right)^{14}$ to 1 resulted in the fast disappearance of the peaks at 526 and $690 \mathrm{~nm}$ due to $\mathbf{1}$ with the formation of a new species (3) (Figures S12 and S13). Interestingly, addition of 1 equiv of HOTf to the solution of $\mathbf{3}$ regenerated $\mathbf{1}$ (Figure S14) (Scheme 2, reaction $b$ ). Thus, the results of the acid-base reaction indicate that addition of base to $\mathbf{1}$ generates a deprotonated species, [(TAML)Fe $\left.\mathrm{IV}^{\mathrm{INTs})}\right]^{2-}(\mathbf{3})$, and $\mathbf{3}$ is converted back to 1 upon protonation (Scheme 2 , reaction $b$ ). Since 3 is not stable $\left(t_{1 / 2} \approx\right.$ $550 \mathrm{~s}$ at $-40^{\circ} \mathrm{C}$ ) (Figure S15) due to disproportionation to [(TAML)Fe $\left.{ }^{\mathrm{V}}(\mathrm{NTs})\right]^{-}$and $\left[\mathrm{Fe}^{\mathrm{III}}(\mathrm{TAML})\right]^{-}$(Figure S16), we were not able to provide strong spectroscopic evidence for 3 except the UV-vis and EPR data. Indeed, such disproportion reaction of $\mathrm{Fe}(\mathrm{IV})$ to $\mathrm{Fe}(\mathrm{V})$ and $\mathrm{Fe}(\mathrm{III})$ is well documented in iron(IV)-oxo porphyrin chemistry. ${ }^{15}$ 
Then, the $K$ values of the deprotonation of 1 with 4-DMAPy and 4-APy were determined by fitting of the titration data (see SI, Experimental Section and Figures S17-S20). The $\mathrm{p} K_{\mathrm{a}}$ of 1 was then determined to be 15.7(1) with the $K$ values and the $\mathrm{p} K_{\mathrm{a}}$ s of 4-DMAPy and 4-APy (eq 1). In addition, with the determined $\mathrm{p} K_{\mathrm{a}}$ value of 1 , the BDE value of $\mathrm{Fe}-\mathrm{N}(\mathrm{H}) \mathrm{Ts}$ in 1 was also determined to be $79.3 \mathrm{kcal} \mathrm{mol}^{-1}$ from the $E_{\text {red }}$ value (vs $\mathrm{Fc}+/ \mathrm{Fc}$ ) of 2 using eq 2, ${ }^{16}$ where $E_{\text {red }}(\mathrm{vs} \mathrm{Fc}+/ \mathrm{Fc})$ of $2=-0.07 \mathrm{~V}$ (Figure S21). 1 is less basic with the lower BDE than those of $\mathrm{L}^{\text {mes }} \mathrm{Fe}^{\mathrm{III}}-\mathrm{N}(\mathrm{H}) \mathrm{Ad}^{+}$, an iron(III)-amido with $\mathrm{p} K_{\mathrm{a}}=37$ and $\mathrm{BDE}=88(5) \mathrm{kcal} \mathrm{mol}$ ${ }^{-1}$, which may result from several factors including the nature of the amide substituent, $\mathrm{Fe}$ oxidation state, and charge of the complex. ${ }^{17}$

$$
\begin{gathered}
\mathrm{p} K_{\mathrm{a},(1)}=-\log K+\mathrm{p} K_{\mathrm{a},(4-\mathrm{X}-\mathrm{py})} \\
\mathrm{BDE}=1.37 \mathrm{p} K_{\mathrm{a},(1)}+23.06 E_{\mathrm{red}}+59.4
\end{gathered}
$$

With the spectroscopically well characterized $\mathbf{1}$ and $\mathbf{2}$, we investigated the $\mathrm{H}$ atom abstraction reaction of $\mathbf{2}$ (Scheme 1B, reaction a) and the $\mathrm{N}$-rebound reaction of $\mathbf{1}$ (Scheme $1 \mathrm{~B}$, reaction $b)$; triphenylmethane $\left(\mathrm{Ph}_{3} \mathrm{CH}\right)$ was used as a substrate. First, the reaction of 2 with $\mathrm{Ph}_{3} \mathrm{CH}$ yielded [Fe ${ }^{\mathrm{III}}$ (TAML) $]^{-}$and $\mathrm{Ph}_{3} \mathrm{C}$-NHTs (Figures $\left.\mathrm{S} 22-\mathrm{S} 24\right)$. The second-order rate constant of the reaction of 2 with $\mathrm{Ph}_{3} \mathrm{CH}$ was determined at different temperatures and then extrapolated to $-40{ }^{\circ} \mathrm{C}$ (Figures S25-S27), ${ }^{18}$ in which the second-order rate constant was determined to be $7.5 \times 10^{-5} \mathrm{M}^{-1} \mathrm{~s}^{-1}$ at $-40{ }^{\circ} \mathrm{C}$ (Scheme $1 \mathrm{~B}$, reaction a). Then, we examined the N-rebound reaction of 1 with triphenylmethyl radical $\left(\mathrm{Ph}_{3} \mathrm{C}^{*}\right)$ (Scheme 1B, reaction $b$, also see Scheme 2, reaction c). Addition of $\left(\mathrm{Ph}_{3} \mathrm{C}\right)_{2}$, which is in equilibrium with $\mathrm{Ph}_{3} \mathrm{C}^{\bullet},{ }^{19}$ to a deaerated $\mathrm{MeCN}$ solution of $\mathbf{1}$ at $-40{ }^{\circ} \mathrm{C}$ under an $\mathrm{Ar}$ atmosphere afforded the $\mathrm{Ph}_{3} \mathrm{C}-\mathrm{NHTs}$ and $\left[\mathrm{Fe}^{\mathrm{III}}(\mathrm{TAML})\right]^{-}$products in $\sim 90 \%$ yield (Figures $\mathrm{S} 28$ and S29). The rate constant of the $\mathrm{N}$-rebound reaction between 1 and $\mathrm{Ph}_{3} \mathrm{C}$ at $-40{ }^{\circ} \mathrm{C}$ was estimated to be larger than $2.4 \times 10^{3} \mathrm{M}^{-1} \mathrm{~s}^{-1}$ from the first-order rate constant $\left(7.2 \times 10^{-3} \mathrm{~s}^{-1}\right)$ in Figure S30, inset, and the maximum concentration of $\left[\mathrm{Ph}_{3} \mathrm{C}^{*}\right]\left(<3 \times 10^{-6} \mathrm{M}\right)$ in the equilibrium with $\left(\mathrm{Ph}_{3} \mathrm{C}\right)_{2} \cdot{ }^{20}$ Thus, by comparing the rate constants of the $\mathrm{H}$ atom abstraction of $\mathrm{Ph}_{3} \mathrm{CH}$ by 2 $\left(7.5 \times 10^{-5} \mathrm{M}^{-1} \mathrm{~s}^{-1}\right)$ and the N-rebound reaction between 1 and $\mathrm{Ph}_{3} \mathrm{C}^{\bullet}\left(2.4 \times 10^{3} \mathrm{M}^{-1} \mathrm{~s}^{-1}\right)$, we can conclude that the $\mathrm{N}$-rebound reaction (Scheme $1 \mathrm{~B}$, reaction $b$ ) is more than $3.2 \times 10^{7}$ times faster than the $\mathrm{H}$ atom abstraction reaction (Scheme 1B, reaction a).

Finally, the reaction of 1 with TEMPOH (BDE of O-H $\left.=70.6 \mathrm{kcal} \mathrm{mol}^{-1}\right)^{16 \mathrm{c}}$ was investigated (Scheme 2, reaction d). Addition of TEMPOH to $\mathbf{1}$ in $\mathrm{MeCN}$ at $-40{ }^{\circ} \mathrm{C}$ resulted in the disappearance of 1 (Figure S31). The second-order rate constant $\left(K_{2}\right)$ was determined to be $1.6 \times 10^{2} \mathrm{M}^{-1} \mathrm{~s}^{-1}$ at $-40{ }^{\circ} \mathrm{C}$ (Figure S32). Product analysis revealed the formation of $\mathrm{NH}_{2}$ Ts and TEMPO ${ }^{\circ}$ with the yields of $\sim 95 \%$ and $\sim 86 \%$, respectively, as the organic products (Figures S33 and S34) and the formation of $\left[\mathrm{Fe}^{\mathrm{III}}(\mathrm{TAML})\right]^{-}$as the decay product of 1 (Figure S35); the overall reaction stoichiometry is shown in eq 3. 


$$
\begin{aligned}
& {\left[(\mathrm{TAML}) \mathrm{Fe}^{\mathrm{IV}}\left(\mathrm{NHT}_{\mathrm{S}}\right)\right]^{-}(1)+\mathrm{TEMPOH} \rightarrow} \\
& {\left[\left(\mathrm{TAML}^{\mathrm{F}} \mathrm{Fe}^{\mathrm{III}}\right]^{-}+\mathrm{NH}_{2} \mathrm{Ts}+\mathrm{TEMPO}\right. \text {. }}
\end{aligned}
$$

In summary, we have reported the synthesis and characterization of a mononuclear nonheme iron(IV)-amido complex, [(TAML) $\left.\mathrm{Fe}^{\mathrm{IV}}(\mathrm{NHTs})\right]^{-}$(1). We have also reported the chemical properties and reactions of the iron(IV)-amido complex, such as the $\mathrm{p} K_{\mathrm{a}}$ and BDE values and the $\mathrm{N}$-rebound and $\mathrm{H}$ atom abstraction reactions.

\section{Supplementary Material}

Refer to Web version on PubMed Central for supplementary material.

\section{ACKNOWLEDGMENTS}

This work was supported by the NRF of Korea through CRI (NRF-2012R1A3A2048842). P.M. thanks GENCI for HPC resources (Grant A0040807648). J.-M.L. and P.M. thank the French National Agency for Research (ANR; ARCANE project no. ANR-11-LABX-003). The SSRL SMB resource was supported by an NIH P41 Resource grant (P41GM103393) and by the DOE Office of Biological and Environmental Research.

\section{REFERENCES}

(1). (a)Huang X; Groves JT Oxygen Activation and Radical Transformations in Heme Proteins and Metalloporphyrins. Chem. Rev 2018, 118, 2491-2553. [PubMed: 29286645] (b)Yosca TH; Ledray AP; Ngo J; Green MT A New Look at the Role of Thiolate Ligation in Cytochrome P450. J. Biol. Inorg. Chem 2017, 22, 209-220. [PubMed: 28091754] (c)Yosca TH; Green MT Preparation of Compound I in P450 cam: The Prototypical P450. Isr. J. Chem 2016, 56, 834-840. (d)(de Montellano Ortiz, Hydrocarbon PR Hydroxylation by Cytochrome P450 Enzymes. Chem. Rev 2010, 110, 932-948. [PubMed: 19769330] (e)Shaik S; Cohen S; Wang Y; Chen H; Kumar D; Thiel W. P450 Enzymes: Their Structure, Reactivity, and Selectivity-Modeled by QM/MM Calculations. Chem. Rev 2010, 110, 949-1017. [PubMed: 19813749]

(2). (a)Solomon EI; Goudarzi S; Sutherlin $\mathrm{KD} \mathrm{O}_{2}$ Activation by Non-Heme Iron Enzymes. Biochemistry 2016, 55, 6363-6374. [PubMed: 27792301] (b)Kal S; Que L. Dioxygen Activation by Nonheme Iron Enzymes with the 2-His-1-Carboxylate Facial Triad that Generate High-Valent Oxoiron Oxidants. J. Biol. Inorg. Chem 2017, 22, 339-365. [PubMed: 28074299]

(3). (a)Nam W; Lee Y-M; Fukuzumi S. Hydrogen Atom Transfer Reactions of Mononuclear Nonheme Metal-Oxygen Intermediates. Acc. Chem. Res 2018, 51, 2014-2022. [PubMed: 30179459] (b)Engelmann X; Monte-Pérez I; Ray K. Oxidation Reactions with Bioinspired Mononuclear Non-Heme Metal-Oxo Complexes. Angew. Chem., Int. Ed 2016, 55, 7632-7649.(c)Puri M; Que L Jr. Toward the Synthesis of More Reactive S $=2$ Non-Heme Oxoiron(IV) Complexes. Acc. Chem. Res 2015, 48, 2443-2452. [PubMed: 26176555] (d)Cook SA; Borovik AS Molecular Designs for Controlling the Local Environments around Metal Ions. Acc. Chem. Res 2015, 48, 2407-2414. [PubMed: 26181849] (e)Nam W; Lee Y-M; Fukuzumi S. Tuning Reactivity and Mechanism in Oxidation Reactions by Mononuclear Nonheme Iron(IV)-Oxo Complexes. Acc. Chem. Res 2014, 47, 1146-1154. [PubMed: 24524675]

(4. (a)Huang X; Groves JT Beyond Ferryl-Mediated Hydroxylation: 40 Years of the Rebound Mechanism and C-H Activation. J. Biol. Inorg. Chem 2017, 22, 185-207. [PubMed: 27909920] (b)Cho K-B; Hirao H; Shaik S; Nam W. To Rebound or Dissociate? This is the Mechanistic Question in C-H Hydroxylation by Heme and Nonheme Metal-Oxo Complexes. Chem. Soc. Rev 2016, 45, 1197-1210. [PubMed: 26690848]

(5). Zaragoza JPT; Yosca TH; Siegler MA; Moënne-Loccoz P; Green MT; Goldberg DP Direct Observation of Oxygen Rebound with an Iron-Hydroxide Complex. J. Am. Chem. Soc 2017, 139, 13640-13643. [PubMed: 28930448] 
(6). Pangia TM; Davies CG; Prendergast JR; Gordon JB; Siegler MA; Jameson GNL; Goldberg DP Observation of Radical Rebound in a Mononuclear Nonheme Iron Model Complex. J. Am. Chem. Soc 2018, 140, 4191-4194. [PubMed: 29537258]

(7). (a)Green MT; Dawson JH; Gray HB Oxoiron(IV) in Chloroperoxidase Compound II Is Basic: Implications for P450 Chemistry. Science 2004, 304, 1653-1656. [PubMed: 15192224] (b)Yosca TH; Rittle J; Krest CM; Onderko EL; Silakov A; Calixto JC; Behan RK; Green MT Iron(IV)hydroxide $\mathrm{pK}_{\mathrm{a}}$ and the Role of Thiolate Ligation in $\mathrm{C}-\mathrm{H}$ Bond Activation by Cytochrome P450. Science 2013, 342, 825-829. [PubMed: 24233717] (c)Krest CM; Silakov A; Rittle J; Yosca TH; Onderko EL; Calixto JC; Green MT Significantly Shorter Fe-S Bond in Cytochrome P450-I is Consistent with Greater Reactivity Relative to Chloroperoxidase. Nat. Chem 2015, 7, 696-702. [PubMed: 26291940] (d)Onderko EL; Silakov A; Yosca TH; Green MT Characterization of a Selenocysteine-Ligated P450 Compound I Reveals Direct Link between Electron Donation and Reactivity. Nat. Chem 2017, 9, 623-628. [PubMed: 28644466]

(8). (a)Yosca TH; Langston MC; Krest CM; Onderko EL; Grove TL; Livada J; Green MT Spectroscopic Investigations of Catalase Compound II: Characterization of an Iron(IV) Hydroxide Intermediate in a Non-Thiolate-Ligated Heme Enzyme. J. Am. Chem. Soc 2016, 138, 16016-16023. [PubMed: 27960340] (b)Wang X; Ullrich R; HofTichter M; Groves JT HemeThiolate Ferryl of Aromatic Peroxygenase is Basic and Reactive. Proc. Natl. Acad. Sci U. S. A. 2015, 112, 3686-3691. [PubMed: 25759437]

(9). (a)Che C-M; Lo VK-Y; Zhou C-Y; Huang J-S Selective Functionalisation of Saturated C-H Bonds with Metalloporphyrin Catalysts. Chem. Soc. Rev 2011, 40, 1950-1975. [PubMed: 21387046] (b)Saouma CT; Peters JC M=E and M=E Complexes of Iron and Cobalt that Emphasize ThreeFold Symmetry (E=O, N, NR). Coord. Chem. Rev 2011, 255, 920-937. [PubMed: 21625302] (c)Eikey RA; Abu-Omar MM Nitrido and Imido Transition Metal Complexes of Groups 6-8. Coord. Chem. Rev 2003, 243, 83-124.(d)Berry JF Terminal Nitrido and Imido Complexes of the Late Transition Metals. Comments Inorg. Chem 2009, 30, 28-66.(e)Zhang L; Deng L. C-H Bond Amination by Iron-Imido/Nitrene Species. Chin. Sci. Bull 2012, 57, 2352-2360.

(10). (a)Hong S; Sutherlin KD; Vardhaman AK; Yan JJ; Park S; Lee Y-M; Jang S; Lu X; Ohta T; Ogura T; Solomon EI; Nam W. A Mononuclear Nonheme Iron(V)-Imido Complex. J. Am. Chem. Soc 2017, 139, 8800-8803. [PubMed: 28628312] (b)Hong S; Lu X; Lee Y-M; Seo MS; Ohta T; Ogura T; Clémancey M; Maldivi P; Latour J-M; Sarangi R; Nam W. Achieving One-Electron Oxidation of a Mononuclear Nonheme Iron(V)-Imido Complex. J. Am. Chem. Soc 2017, 139, 14372-14375. [PubMed: 28960973]

(11). Collins TJ; Fox BG; Hu ZG; Kostka KL; Münck E; Rickard CEF; Wright LJ High Valent Transition Metal Chemistry. Synthesis and Characterization of an Intermediate-Spin Iron(IV) Complex of a Strong $\pi$-Acid Ligand. J. Am. Chem. Soc 1992, 114, 8724-8725.

(12). Sarangi R X-ray Absorption Near-Edge Spectroscopy in Bioinorganic Chemistry: Application to M-O 2 Systems. Coord. Chem. Rev 2013, 257, 459-472. [PubMed: 23525635]

(13). Westre TE; Kennepohl P; DeWitt JG; Hedman B; Hodgson KO; Solomon EI A Multiplet Analysis of Fe K-Edge 1s $\rightarrow$ 3d Pre-Edge Features of Iron Complexes. J. Am. Chem. Soc 1997, 119, 6297-6314.

(14). Spillane WJ; O’Byrne A; McCaw CJA Elimination Mechanisms in the Aminolysis of Sulfamate Esters of the Type $\mathrm{NH}_{2} \mathrm{SO}_{2} \mathrm{OC}_{6} \mathrm{HX}-$ Models of Enzyme Inhibitors. Eur. J. Org. Chem 2008, 2008, 4200-4205.

(15. (a)Pan Z; Newcomb M. Kinetics and Mechanism of Oxidation Reactions of Porphyrin-Iron(IV)Oxo Intermediates. Inorg. Chem 2007, 46, 6767-6774. [PubMed: 17630728] (b)Pan Z; Newcomb M. Acid-Catalyzed Disproportionation of Oxoiron(IV) Porphyrins to Give Oxoiron(IV) Porphyrin Radical Cations. Inorg. Chem. Commun 2011, 14, 968-970. [PubMed: 21572532]

(16). (a)Mayer JM Hydrogen Atom Abstraction by Metal-Oxo Complexes: Understanding the Analogy with Organic Radical Reactions. Acc. Chem. Res 1998, 31, 441-450.(b)Green MT C-H Bond Activation in Heme Proteins: The Role of Thiolate Ligation in Cytochrome P450. Curr. Opin. Chem. Biol 2009, 13, 84-88. [PubMed: 19345605] (c)Warren JJ; Tronic TA; Mayer JM Thermochemistry of Proton-Coupled Electron Transfer Reagents and its Implications. Chem. Rev 2010, 110, 6961-7001. [PubMed: 20925411] 
(17). Nieto I; Ding F; Bontchev RP; Wang H; Smith JM Thermodynamics of Hydrogen Atom Transfer to a High-Valent Iron Imido Complex. J. Am. Chem. Soc 2008, 130, 2716-2717. [PubMed: 18266366]

(18). The rate constant of hydrogen atom transfer from triphenylmethane to $\mathbf{2}$ has been included in the previously reported plot of $\log \mathrm{k}_{2}$ ' vs BDEs of substrates (ref $10 \mathrm{a}$ ) at $15^{\circ} \mathrm{C}$ in the SI, Figure $\mathrm{S} 27.2_{2}$

(19). (a)Colle TH; Glaspie PS; Lewis ES The Triphenylmethyl Radical: Equilibrium Measurements and the Reaction with Thiophenol. J. Org. Chem 1978, 43, 2722-2725.(b)Jang ES; McMullin CL; Kafi M; Meyer K; Cundari TR; Warren TH Copper(II) Anilides in $\mathrm{sp}^{3}$ C-H Amination. J. Am. Chem. Soc 2014, 136, 10930-10940. [PubMed: 24940616] (c)Iovan DA; Betley TA Characterization of Iron-Imido Species Relevant for N-Group Transfer Chemistry. J. Am. Chem. Soc 2016, 138, 1983-1993. [PubMed: 26788747]

(20). The concentration of $\mathrm{Ph}^{\circ} \mathrm{C}^{\bullet}$ during the reaction was too small to be detected, being estimated to be smaller than $3 \times 10^{-6} \mathrm{M}$ from $\Delta \mathrm{A}(<0.001)$ based on the $\varepsilon$ value at $514 \mathrm{~nm}$ due to $\mathrm{Ph}_{3} \mathrm{C}^{\bullet}(\mathrm{SI}$, Experimental Section). The reaction of 1 with $\mathrm{Ph}_{3} \mathrm{C}^{\bullet}$ was much faster than the formation of $\mathrm{Ph}_{3} \mathrm{C}^{\bullet}$ from the dimer (SI, Figure S30). ${ }^{\bullet} \mathbf{6}_{3} \mathbf{1}_{3} \mathbf{3}^{\bullet}$ 

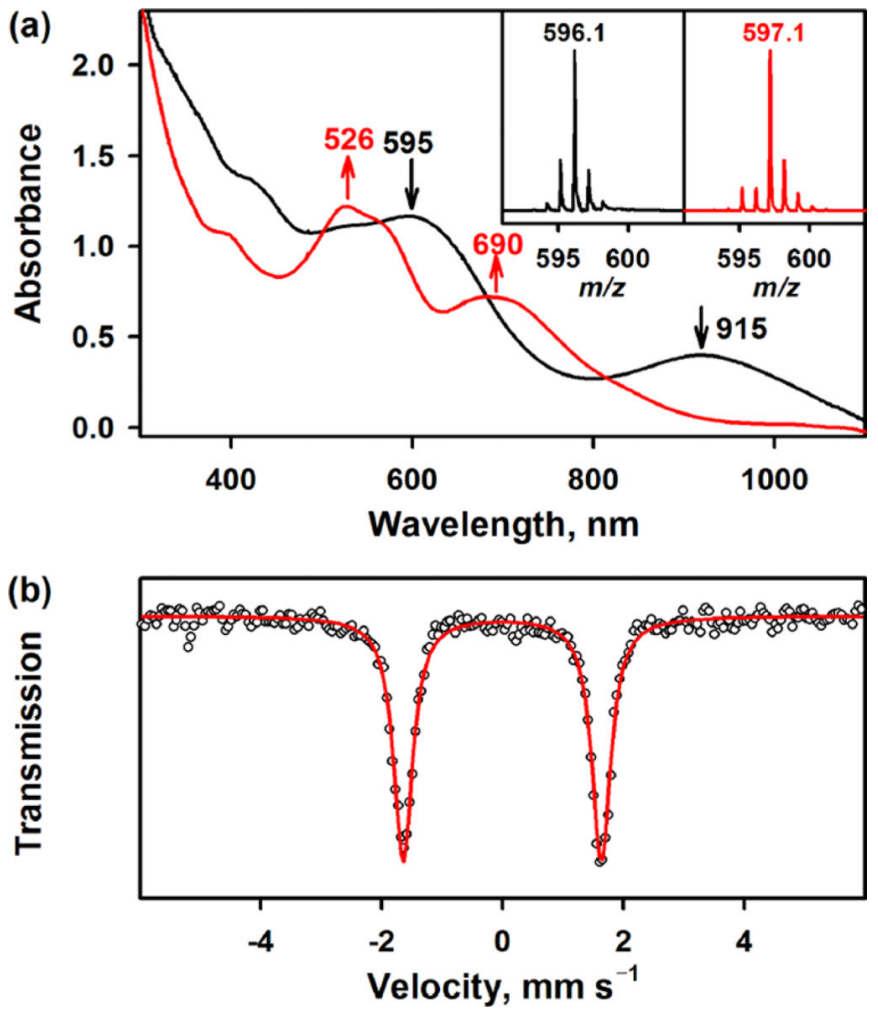

Figure 1.

(a) UV-vis spectra of $\left[\mathrm{Fe}^{\mathrm{V}}(\mathrm{NTs})(\mathrm{TAML})\right]^{-}$(2, black line) and $\left[\mathrm{Fe}^{\mathrm{IV}}(\mathrm{NHTs})(\mathrm{TAML})\right]^{-}(\mathbf{1}$, red line). 1 was synthesized by reacting $2(0.20 \mathrm{mM})$ with 1.0 equiv of TEMPOH $(0.20 \mathrm{mM})$ in $\mathrm{MeCN}$ at $-40{ }^{\circ} \mathrm{C}$. Insets show CSI-MS spectra with the isotopic distribution patterns of the peaks at $m / z 596.1$ for $\mathbf{1}^{14} \mathrm{NHTs}$ (left panel) and at $\mathrm{m} / \mathrm{z} 597.1$ for $\mathbf{1}^{1}{ }^{15} \mathrm{NTs}$ ( right panel). (b) Mössbauer spectra (black circles) with fits (red line) for 1 recorded at $80 \mathrm{~K}$ and $0 \mathrm{~T}$. The solid line is a calculated spectrum with the following parameters: $\delta=-0.01 \mathrm{~mm} \mathrm{~s}^{-1}$ and $\Delta E_{\mathrm{Q}}=3.28 \mathrm{~mm} \mathrm{~s}^{-1}$. 
(a)

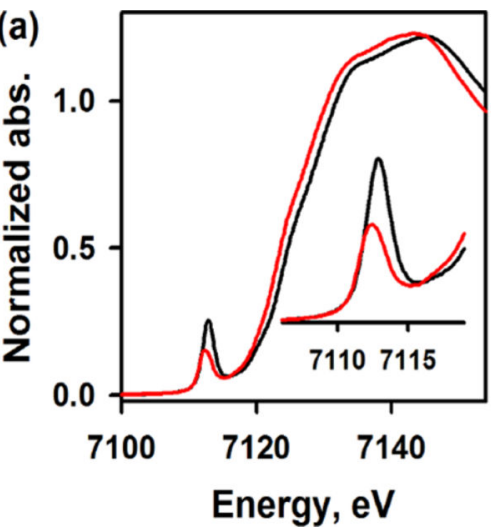

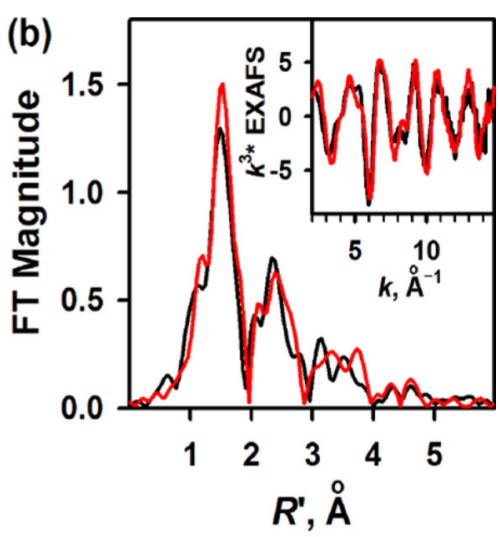

Figure 2.

(a) Normalized Fe K-edge XAS data for $\mathbf{1}$ (red) and $\mathbf{2}$ (black). The inset shows the expanded pre-edge region. (b) Non-phase-shift-corrected Fourier transform (FT) data for $\mathbf{1}$ (red) and $\mathbf{2}$ (black). The inset shows the EXAFS data. 


$$
\begin{aligned}
& \text { (A) } \mathrm{O} \quad \mathrm{R}_{3} \mathrm{C} \cdot \mathrm{OH} \quad \text { O-rebound } \mathrm{R}_{3} \mathrm{COH}
\end{aligned}
$$

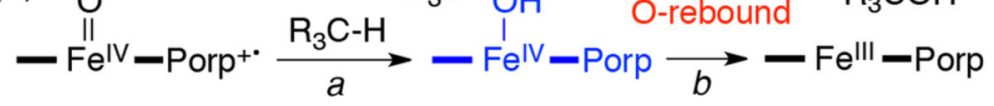

$$
\begin{aligned}
& \text { (B) NTs } \quad \mathrm{R}_{3} \mathrm{C} \cdot \mathrm{NHTs} \quad \mathrm{N} \text {-rebound } \mathrm{R}_{3} \mathrm{CNHTs} \\
& \text { - } \mathrm{Fe}^{\mathrm{V}}-\mathrm{TAML} \underset{\mathrm{a}}{\stackrel{\mathrm{R}_{3} \mathrm{C}-\mathrm{H}}{\longrightarrow}}-\mathrm{Fe}^{\mathrm{IV}}-\mathrm{TAML} \underset{b}{\stackrel{\mathrm{I}}{\longrightarrow}}-\mathrm{Fe}^{\mathrm{III}}-\mathrm{TAML}
\end{aligned}
$$

Scheme 1.

C-H Bond Activation Reactions of Cpd-I and Fe(V)-Imido Complex 


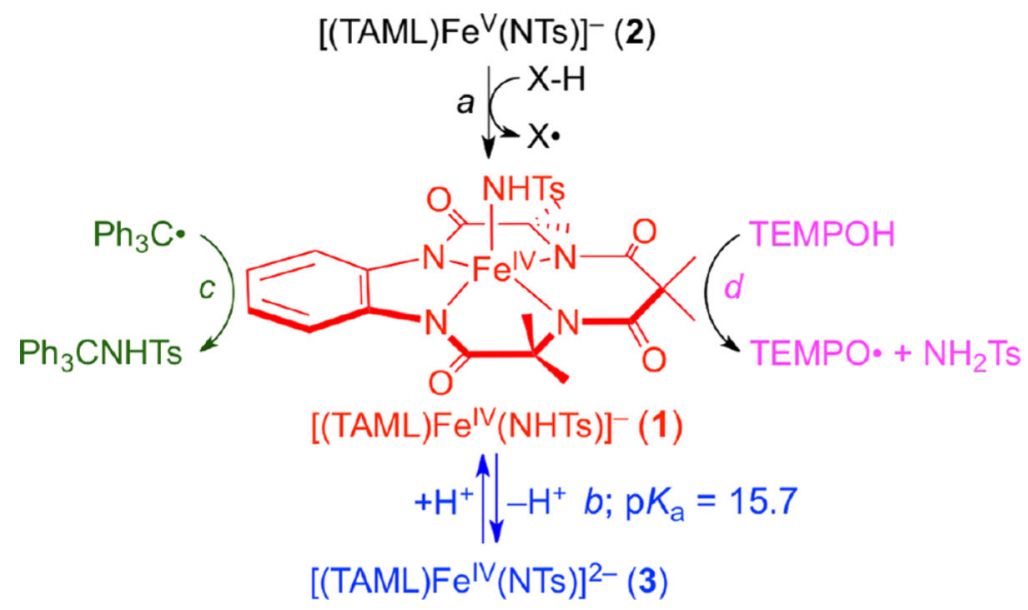

Scheme 2.

Schematic Representation for the Synthesis and Reactions of [(TAML)Fe $\left.{ }^{\mathrm{IV}}(\mathrm{NHTs})\right]^{-}$ 